\title{
A Comparative Study on Criminal Sanction Against Drugs Offenders
}

\author{
Monalisa ; Sri Rahayu ${ }^{\star \star}$; Dheny Wahyudhi ${ }^{\star \star \star}$ \\ Faculty of Law, Universitas Jambi \\ ^lisamona675@gmail.com

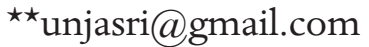 \\ ${ }^{\star \star \star}$ dhenywahyudi@unja.ac.id
}

\section{Abstract}

This article seeks to compare the criminal sanction regulation upon narcotics offences between Indonesian Narcotics Law and Singapore Drugs Act. Indonesia and Singapore have shared commitments to eradicate drugs offences in its respective country. Despite their similarity, however, both countries also have different approach to be applied in their respective laws to eradicate drugs offence. Methodogically normative, a comparative is exercised in order to reveal to what extent do Indonesia and Singapore have similarities and differences in applying sanction upon drug offenders and how both countries manage to eradicate the offence. Despite its success to significantly decrease number of narcotics offences due to its strict approach in its appliaction and resulting in deterrence effect for criminal offenders, Singapore shall not be compared to Indonesia. Not only because both countries have different system of law but also face different character of region. Besides, Indonesia is much bigger than Singapore. Despites sharing differences, both country may learn, share, and cooperate each other in order to more effectively eradicate drugs offences in the both coutries.

Keywords: Compariative Study; Drugs Offences; Criminal Sanction; Indonesian Narcotics Law; Singapore Drugs Act 


\section{A. Introduction}

Drugs offence has been playing a significant role as a trans-national crime both in Indonesia and Singapore. As countries with bold commitment to eradicate drugs in these regions, Indonesia and Singapore are still facing problems with respect to which sanctions have to be imposed against the drugs offenders.

As one of the biggest archipelagic state in the world, Indonesia tend to face more risks due to its strategic location in South East Asia, resulting in high traffic numbers of domestic and international drugs transactions. Concerning the fact that Indonesia is one of the signatories of the United Nations (UN) conventions regarding narcotics, ${ }^{1}$ Indonesian government has put effort to eradicate the offences through its Law Number 35/2009 on Narcotics (hereby referred to as Indonesian Narcotics Law). ${ }^{2}$

In Indonesian law, criminalization is a part of the criminal system in which the definition of the sanction is pivotal. ${ }^{3}$ In general sense, criminal sanction is a penalty against offence in the form of pain deliberately imposed by the state upon the offender. ${ }^{4}$ According to Black's Law Dictionary, sanction is a penalty or coercive measure that results from failure to comply with a law, rule, or order (a sanction for discovery abuse) which means a punishment or imperative action resultant from failure to obey the law. ${ }^{5}$

Stipulation of criminal sanction is inseparable from the goal

1 These conventions are UN Single Convention on Narcotic Drugs of 1961 (as amended by the Protocol of 1972); the UN Convention on Psychotropic Substances of 1971; and the UN Convention against the Illicit Traffic in Narcotic Drugs and Psychotropic Substances of 1988.

2 Undang-Undang Nomor 35 Tahun 2009 tentang Narkotika. See Aziz Syamsuddin, Tindak Pidana Khusus (Special Crime), Fifth Edition, Jakarta, Sinar Grafi$\mathrm{ka}, 2016$.

3 Puteri Hikmawati, "Analisis Terhadap Sanksi Pidana Bagi Pengguna Narkotika”, Jurnal Negara Hukum, Vol. 2, No. 2, November 2011, p. 332.

4 Muh Endriyo Susila, The Criminal Law of Indonesia, Yogyakarta, Pensil Komunika, 2014, p. 51. See also Tri Andrisman, Asas-Asas Dan Dasar Aturan Hukum Pidana Indonesia (Principals and Ground Regulation of Criminal Law), Bandar Lampung, Ula, 2009, p. 8.

5 Samsul Ramli and Fahrurrazi, Bacaan Wajib Swakelola Pengadaan Barang/ Jasa, Jakarta, Visimedia Pustaka, 2014, p. 191. 
of criminal policy to provide society protection and welfare. ${ }^{6}$ Karl O. Christiansen has suggested that the fundamental prerequisite of defining a means, method or measure as rational is that the aim or purpose to be achieved is well defined. ${ }^{7}$ Based on Article 4 of the Indonesian Narcotics Law, the aims of the Law are to ensure the availability of Narcotics for the purpose of health and/or the development of science and technology; to prevent, protect and save the people of Indonesia from the abuse of Narcotics; to eradicate illicit traffic of Narcotics and Narcotics Precursor, and to ensure the regulation of the medical and social rehabilitation efforts for abusers and Narcotics addicts. These goals are made based on Indonesian criminalization theory, which is a combination criminalization theory (verenigings theorieen). The philosophy of this theory, as long as the criminal punishment in Indonesia is concerned, is to focus more on the efforts of rehabilitation and social reintegration for perpetrators of criminal acts. ${ }^{8}$

Another country that is also considered to have shared commitment and worth to be compared with Indonesia in eradicating drugs is Singapore. Through consistently law enforcement, Singapore is reported to have the lowest rate narcotics abuse in the world which only 30 opiates abusers per 100,000 people, compared with 600 in the United States. ${ }^{9}$ Singapore's successful factor on pushing narcotics offences rates to the lower rates every year is through criminal sanction regulation on Misuse of Drugs Act (hereby referred to as Singapore Drugs Act) and the criminalization theory.

Recently, Singapore has been reported to have enforced a se-

6 See for example, Despan Heryansyah \& Muhammad Hidayatullah, "Problems of Law Enforcement and Ideas of Paradigm Prophetic in Indonesia," Jambe Law Journal, Vol. 1 No. 1, 2018.

7 Puteri Hikmawati, Loc. Cit.

8 Colman Lynch, “Indonesia’s Use of Capital Punishment For Drug-Trafficking Crimes: Legal Obligations, Extralegal Factors, and The Bali Nine Case”, Columbia Human Rights Law Review, vol. 40, p. 532.

9 Ashok Kumar Mirpuri, "Singapore is Winning the War on Drugs. Here's How”, https://www.washingtonpost.com/opinions/singapore-is-winning-the-war-on-drugs-heres-how/2018 /03/11/b8c25278-22e9-11e8-946c9420060cb7bd_story.html. Accessed on 30 December 2019. 
vere capital punishment. Michael Hor reported, "Singapore achieved global fame, when Amnesty International reported that it had the highest per capita execution rate in the world, dwarfing the rates in rather more prominent death penalty practitioners such as Saudi Arabia, China and the United States." ${ }^{10}$ Singapore prescribes death for crimes such as drug trafficking, murder, terrorism, threatening the internal security of the state, using arms in the commission of certain crimes, and kidnapping. But compared to most other nations that have retained the death penalty, Singapore stands out in two respects: 1) certainty of punishment, and 2) celerity (speed of administration). In Singapore, a death sentence is mandatory for murder, possession of drugs with intent to traffic, and other offenses. As for celerity, homicide trials in Singapore seldom take more than a few months, and death sentence appeals are typically disposed of within 18 months of conviction. In the 2011 Universal Periodic Review, as reported to the U.N. Human Rights Council, the Singapore government defended the use of the death penalty, yet stating that it is used only for the most serious crimes, to send a strong signal to would-be offenders, and to give "deterring" effect. ${ }^{11}$

The application of severe penalties in Singapore have raised debate and concern from the International community. In his own words, the former Prime Minister of Singapore, Lee Kuan Yew, argued the position of Singapore to defend death pealty relies on the fact that "in criminal law legislation, our priority is the security and wellbeing of law-abiding citizens rather than the rights of the criminal to be protected from incriminating evidence. ${ }^{12}$ In similar notion, Professor Li-Ann Thio rebutted such critics as the ones from west-

10 Michael Hor, “The Death Penaly in Singapore and International Law", Singapore Year Book of International Law, Issue 8, Singapore: National University of Singapore, p. 105.

11 Cheah Wui Ling, "Developing a People-Centered Justice in Singapore: In Support of Pro Bono and Innocence Work”, Cincinnati Law Review, Volume 80, Issue 4, Ohio: University of Cincinnati, p. 5.

12 George Baylon Radics, 'Singapore: A 'Fine' City: British Colonial Criminal Sentencing Policies and its Lasting Effects on the Singaporean Corporal State", Santa Clara Journal of International Law, Volume 12, Issue 2, California: Santa Clara University, 2014, p. 63. 
ern thoughts seeming to believe that Siangpore's death penalty have abandoned the very moral law to protect the rights of the individual. She defended that such thoughts are nothing but absurd thinking of libertarian academics and the Western liberal press that Singapore criminal laws are harsh and the legal system so loaded against an accused that no accused can get a fair trial in Singapore." ${ }^{13}$

The discussion concerning the comparative study between Indonesian Narcotics Law and Singapore's Misuse Act can be a media of mutual exchange of idea to formulate better law, especially in Indonesia. The following sections will discuss these explanations in greater details.

\section{B. Results and Discussion}

Legal experts divide legal system into several legal families in order to differentiate one and another based on race, country territory, history, etc. ${ }^{14}$ The first legal experts who arranged legal families classification are Rene David and John E.C. Brierley. They classified legal families into ${ }^{15}$ :

1. The Romano-Germanic Family

2. The Common Law Family

3. The Family of Socialist Law

4. Other Conceptions of Law and Social Order

Marc Ancel divided law families into:

1. Civil Law System/European Continental

2. Common Law System/Anglo Saxon

3. Middle East System

4. Far East System

5. Socialist System

13 Ibid.

14 Beni Ahmad Saebani, Syahrul Anwar, and Ai Wati, Perbandingan Sistem Hukum Pidana (The Comparation of Criminal Legal System), Bandung, Pustaka Setia, 2016, p. 17.

15 Ibid, p. 45. 


\section{Similarity of Narcotics Criminal Sanction Between Indonesia and Singapore}

This table shows how Indonesia and Singapore share similarities in the matter of drugs criminal sanctions:

Table 1: Similarity of Narcotics Criminal Sanction Between the Indonesian Narcotics Law and Singapore Drugs Act

\begin{tabular}{cll}
\hline No. & $\begin{array}{l}\text { Aspects of Simi- } \\
\text { larity }\end{array}$ & $\begin{array}{l}\text { Indonesian Narcotics Law and Singapore Drugs } \\
\text { Act }\end{array}$ \\
\hline 1 & $\begin{array}{l}\text { The limit of sanc- } \\
\text { tion (strafmaat) }\end{array}$ & $\begin{array}{l}\text { Both Laws regulate minimum and maximum of } \\
\text { the imprisonment period. }\end{array}$ \\
\hline 2 & Criminal Type & $\begin{array}{l}\text { Death penalty, life imprisonment, prisoning sen- } \\
\text { tences, and fine penalty. }\end{array}$ \\
\hline 3 & $\begin{array}{l}\text { Sanction imposed } \\
\text { based on narcotics } \\
\text { lass }\end{array}$ & $\begin{array}{l}\text { Both Laws regulate 3 types of narcotics. } \\
\text { In Indonesia: Class I, Class II, Class III. } \\
\text { In Singapore: Class A, Class B, Class C. }\end{array}$ \\
\hline 4 & $\begin{array}{l}\text { Sanction imposed } \\
\text { based on narcotics } \\
\text { quantity }\end{array}$ & $\begin{array}{l}\text { Both Laws regulate that the more heavy and big } \\
\text { narcotics quantity, the more heavy sentences will } \\
\text { be imposed. }\end{array}$ \\
\hline 5 & $\begin{array}{l}\text { Same sanction for } \\
\text { same offences }\end{array}$ & $\begin{array}{l}\text { Both Laws have some precise same sanction for } \\
\text { some offences. (further explanation in table no. 4) }\end{array}$ \\
\hline
\end{tabular}

Both Indonesia and Singapore, in formulating imprisonment period for narcotics criminal sanction, are using minimum and maxi-

Table 2: Minimum and Maximum Limit for Imprisonment

\begin{tabular}{cccc}
\hline \multicolumn{4}{c}{ Imprisonment } \\
\hline Act Number $\mathbf{3 5 / 2 0 0 9}$ on Narcotics & \multicolumn{2}{c}{ Misuse of Drugs Act } \\
\hline Maximum & Minimum & Maximum & Minimum \\
\hline 20 year & 1 year & 30 year & 6 months \\
\hline 15 year & 2 year & 20 year & 12 months \\
\hline 12 year & 3 year & 10 year & 2 year \\
\hline 10 year & 4 year & 5 year & 3 year \\
\hline 7 year & 5 year & 3 year & 4 year \\
\hline 4 year & 6 year & 2 year & 5 year \\
\hline 2 year & - & 12 months & 6 year \\
\hline 1 year & - & - & 10 year \\
\hline 6 months & - & - & 20 year
\end{tabular}


mum limit on imposing imprisonment and fines. Table 2 and 3 show such limits in the provisions of both Laws.

Table 3: Fine Penalty Table

\begin{tabular}{|c|c|c|c|}
\hline \multicolumn{4}{|c|}{ Fine Penalty } \\
\hline \multicolumn{2}{|c|}{ Indonesian Narcotics Law (IDR) } & \multicolumn{2}{|c|}{ Singapore Drugs Act (SGD) } \\
\hline Maximum & Minimum & Maximum & Minimum \\
\hline 20.000 .000 .000 & 40.000 .000 & $\$ 400,000$ & $\$ 1,000$ \\
\hline 10.000 .000 .000 & 60.000 .000 & $\$ 200,000$ & $\$ 2,000$ \\
\hline 8.000 .000 .000 & 100.000 .000 & $\$ 20,000$ & $\$ 4,000$ \\
\hline 5.000 .000 .000 & 400.000 .000 & $\$ 10,000$ & $\$ 5,000$ \\
\hline 3.000 .000 .000 & 500.000 .000 & $\$ 5,000$ & \\
\hline 1.000 .000 .000 & 600.000 .000 & \multirow{2}{*}{\multicolumn{2}{|c|}{$\begin{array}{c}\text { Currency Conversion (Singapore Dol } \\
\text { lar to Indonesian Rupiah) }\end{array}$}} \\
\hline 600.000 .000 & 800.000 .000 & & \\
\hline 500.000 .000 & 1.000 .000 .000 & Maximum & Minimum \\
\hline 400.000 .000 & 2.000 .000 .000 & 4.191 .861 .150 & 10.479 .650 \\
\hline 50.000 .000 & & 2.095 .930 .575 & 20.959 .300 \\
\hline 2.000 .000 & & 209.593 .050 & 41.918 .600 \\
\hline \multirow[t]{2}{*}{1.000 .000} & & 104.796 .525 & 52.398 .275 \\
\hline & & 52.398 .275 & \\
\hline
\end{tabular}

The tables above demonstrate that imprisonment periods in Singapore are longer than the ones in Indonesia. Yet, fine penalties in Indonesia are higher than the ones in Singapore. In general, Indonesia tends to have various fine amounts and uses cumulative system in giving fine; an offender is obliged to pay while being imposed to imprisonment. Unlike Indonesia, imprisonment in Singapore is alternative when it is exercised with fine. Yet it becomes cumulative when it is exercised with caning.

Narcotics types in Indonesia and Singapore differ in 3 categories (Article 6 of Indonesian Narcotics Law and Section 2 of the Singapore Drugs Act).

Another fact that is found from the table is that Indonesia and Singapore have similarities in setting minimum and maximum time limit for same offences. There are minimum limit for 2 years, 3 years, and 5 years, while maximum limits are up to 10 years and 20 years. 
Table 4: Narcotics Offences and Criminalization Time Period

\begin{tabular}{|c|c|c|c|c|}
\hline \multirow[b]{2}{*}{ No. } & \multirow[b]{2}{*}{$\begin{array}{l}\text { Same Narcot- } \\
\text { ics Offences } \\
\text { (Indonesia } \\
\text { and Singa- } \\
\text { pore) }\end{array}$} & \multicolumn{2}{|c|}{ Criminal Sanction } & \multirow[b]{2}{*}{ Same Sanctions } \\
\hline & & $\begin{array}{l}\text { Indonesian } \\
\text { Narcotics } \\
\text { Law }\end{array}$ & $\begin{array}{l}\text { Singa- } \\
\text { pore } \\
\text { Drugs } \\
\text { Act }\end{array}$ & \\
\hline 1. & $\begin{array}{l}\text { Drugs Traf- } \\
\text { ficking }\end{array}$ & $\begin{array}{l}\text { Article } 114, \\
\text { Article } 119, \\
\text { Article } 124\end{array}$ & $\begin{array}{l}\text { Section } \\
5\end{array}$ & $\begin{array}{l}\text { - Class I or Class A: imprison- } \\
\text { ment }=\text { minimum } 5 \text { years and } \\
\text { maximum } 20 \text { years. } \\
\text { - Class III or Class C: impris- } \\
\text { onment = maximum } 10 \text { years. }\end{array}$ \\
\hline 2. & $\begin{array}{l}\text { Drugs Manu- } \\
\text { facturing }\end{array}$ & $\begin{array}{l}\text { Article } 113, \\
\text { Article } 118, \\
\text { Article } 123\end{array}$ & $\begin{array}{l}\text { Section } \\
6\end{array}$ & - \\
\hline 3. & $\begin{array}{l}\text { Import or Ex- } \\
\text { port of Drugs }\end{array}$ & $\begin{array}{l}\text { Article } 113, \\
\text { Article } 118, \\
\text { Article } 123\end{array}$ & $\begin{array}{l}\text { Section } \\
7\end{array}$ & $\begin{array}{l}\text { - Class I or Class A: imprison- } \\
\text { ment,, minimal } 5 \text { years. } \\
\text {-Class III or Class C: imprison- } \\
\text { ment,, minimal } 3 \text { years. }\end{array}$ \\
\hline 4. & $\begin{array}{l}\text { Drugs Posses- } \\
\text { sion }\end{array}$ & $\begin{array}{l}\text { Article } 112, \\
\text { Article } 117, \\
\text { Article } 122\end{array}$ & $\begin{array}{l}\text { Section } \\
8(a)\end{array}$ & $\begin{array}{l}\text { Same provision to the section } \\
8(\mathrm{a}) \text {; Class II and Class III (nar- } \\
\text { cotics quantity more than } 5 \mathrm{~g}) \text { : } \\
\text { imprisonment }=\text { maximum } 10 \\
\text { years. }\end{array}$ \\
\hline 5. & $\begin{array}{l}\text { Drugs Con- } \\
\text { sumption }\end{array}$ & $\begin{array}{l}\text { Article } 127 \\
\text { point (1) }\end{array}$ & $\begin{array}{l}\text { Section } \\
8(\mathrm{~b})\end{array}$ & - \\
\hline 6. & $\begin{array}{l}\text { Drugs Culti- } \\
\text { vation }\end{array}$ & Article 111 & $\begin{array}{l}\text { Section } \\
10\end{array}$ & $\begin{array}{l}\text { Same provision to the Section } \\
10 \text { for Class I (more than } 1 \mathrm{~kg} \\
\text { or } 5 \text { trees): imprisonment }= \\
\text { maximum } 20 \text { years. }\end{array}$ \\
\hline 7. & $\begin{array}{l}\text { Drugs Precur- } \\
\text { sor }\end{array}$ & Article 129 & $\begin{array}{l}\text { Section } \\
10 \mathrm{~A}\end{array}$ & $\begin{array}{l}\text { Imprisonment }=\text { maximum } 20 \\
\text { years. }\end{array}$ \\
\hline 8. & $\begin{array}{l}\text { Causing or } \\
\text { procuring } \\
\text { young } \\
\text { person or } \\
\text { vulnerable } \\
\text { person to } \\
\text { commit cer- } \\
\text { tain offences }\end{array}$ & $\begin{array}{l}\text { Article } 133 \\
\text { point (1) }\end{array}$ & $\begin{array}{l}\text { Section } \\
12 \mathrm{~A}\end{array}$ & $\begin{array}{l}\text { Same provision for Class C: } \\
\text { imprisonment, maximum } 20 \\
\text { years. }\end{array}$ \\
\hline
\end{tabular}




\begin{tabular}{|c|c|c|c|c|}
\hline 9. & $\begin{array}{l}\text { Probation, } \\
\text { and abetting } \\
\text { or procuring } \\
\text { the } \\
\text { Commission } \\
\text { of narcotics } \\
\text { offences }\end{array}$ & $\begin{array}{l}\text { Article } 132 \\
\text { point (1) }\end{array}$ & $\begin{array}{l}\text { Section } \\
13\end{array}$ & $\begin{array}{l}\text {-Article } 132 \text { poin ( } 1 \text { ) is regulat- } \\
\text { ing the probation and abetting } \\
\text { in narcotics offences based on } \\
\text { article } 111,112,113,114,115 \text {, } \\
116,117,118,119,120,121 \text {, } \\
122,123,124,125,126 \text {, and } \\
129 . \\
\text { - imprisonment, for maxi- } \\
\text { mum } 10 \text { years on Section } 13 \text { is } \\
\text { same with maximum provi- } \\
\text { sion on Article } 117 \text { point ( } 1) \\
\text { for Class II, Article } 122 \text { point } \\
\text { (2) for Class III with quantity } \\
\text { more than } 5 \text { g, Article } 123 \\
\text { point ( } 1 \text { ) for Class III, Article } \\
124 \text { point ( } 1 \text { ) for Class III, Ar- } \\
\text { ticle } 120 \text { point ( } 1 \text { ) for Class II, } \\
\text { Article } 125 \text { point ( } 2 \text { ) for Class } \\
\text { III with quantity more than } \\
5 \mathrm{~g} \text {, and Article } 126 \text { point (1) } \\
\text { for Class III. } \\
\text { - imprisonment, for minimal } \\
2 \text { years on Section } 13 \text { is same } \\
\text { with minimal sanction provi- } \\
\text { sion on Article } 122 \text { point ( } 1 \text { ) } \\
\text { for Class III, and Article } 125 \\
\text { point ( } 1 \text { ) for Class III. }\end{array}$ \\
\hline 10. & $\begin{array}{l}\text { Obstructing } \\
\text { law enforce- } \\
\text { ments }\end{array}$ & Article 138 & $\begin{array}{l}\text { Section } \\
30(1)(a)\end{array}$ & - \\
\hline 11. & $\begin{array}{l}\text { Giving false } \\
\text { information }\end{array}$ & Article 143 & $\begin{array}{l}\text { Section } \\
30(1)(d)\end{array}$ & - \\
\hline 12. & $\begin{array}{l}\text { Narcotics Re- } \\
\text { habilitation }\end{array}$ & $\begin{array}{l}\text { Article } 127 \\
\text { point }(3)\end{array}$ & $\begin{array}{l}\text { Section } \\
34\end{array}$ & Medical rehabilitation \\
\hline 13. & $\begin{array}{l}\text { Sanctions for } \\
\text { corporation }\end{array}$ & Article 130 & $\begin{array}{l}\text { Section } \\
14\end{array}$ & - \\
\hline
\end{tabular}

\section{Distinction of Narcotics Criminal Sanction Between Indonesia and Singapore}

The table below shows the distinctions between Indonesia and Singapore in terms of forms of sanction: 
Table 5: Narcotics Criminal Sanction in Indonesian Narcotics Law and Singapore Drugs Act

\begin{tabular}{|c|c|c|c|}
\hline No. & $\begin{array}{l}\text { Aspects } \\
\text { of Dis- } \\
\text { tinctions }\end{array}$ & Indonesian Narcotics Law & Singapore Drugs Act \\
\hline 1. & $\begin{array}{l}\text { Sentenc- } \\
\text { es Types }\end{array}$ & $\begin{array}{l}\text {-without caning. } \\
\text {-with confinement sen- } \\
\text { tences. }\end{array}$ & $\begin{array}{l}\text {-with caning. } \\
\text {-without confinement sen- } \\
\text { tences. }\end{array}$ \\
\hline 2. & $\begin{array}{l}\text { Criminal- } \\
\text { ization } \\
\text { System }\end{array}$ & $\begin{array}{l}\text {-imprisonment is alternative } \\
\text { with death penalty and life } \\
\text { imprisonment, but impris- } \\
\text { onment is cumulative with } \\
\text { fine penalty. } \\
\text {-Confinement sentences is } \\
\text { alternative with fine penalty. }\end{array}$ & $\begin{array}{l}\text {-imprisonment is cumulative } \\
\text { with caning sentences. } \\
\text {-Life imprisonment is alterna- } \\
\text { tive with imprisonment. } \\
\text {-Death penalty is imposed } \\
\text { without substitution as single } \\
\text { sanction. } \\
\text {-imprisonment is alternative- } \\
\text { cumulative with fine penalty. }\end{array}$ \\
\hline 3. & $\begin{array}{l}\text { Fine } \\
\text { Penalty }\end{array}$ & $\begin{array}{l}\text { Regulated in some articles } \\
\text { that maximum fine shall be } \\
\text { made heavier by adding } 1 / 3 \\
\text { to the maximum fine. }\end{array}$ & Only regular fine penalty. \\
\hline 4. & $\begin{array}{l}\text { Sanction } \\
\text { Provision }\end{array}$ & $\begin{array}{l}\text { On imposing sentences, } \\
\text { many articles are relates one } \\
\text { and anothers. }\end{array}$ & $\begin{array}{l}\text { Criminal sanctions are im- } \\
\text { posed one by one. }\end{array}$ \\
\hline 5. & $\begin{array}{l}\text { Judge's } \\
\text { Consid- } \\
\text { eration }\end{array}$ & $\begin{array}{l}\text {-No special provision to } \\
\text { impose death penalty upon } \\
\text { offender. } \\
\text { - Judge may consider giving } \\
\text { rehabilitation upon of- } \\
\text { fender. }\end{array}$ & $\begin{array}{l}\text { Judge may choose to impose } \\
\text { life imprisonment than death } \\
\text { penalty in special or excep- } \\
\text { tional conditions. }\end{array}$ \\
\hline 6. & $\begin{array}{l}\text { Sanction } \\
\text { based on } \\
\text { narcotics } \\
\text { quantity }\end{array}$ & $\begin{array}{l}\text { Based on Class I, Class II, } \\
\text { and Class III. (all types) }\end{array}$ & $\begin{array}{l}\text { Only for opium, opium } \\
\text { containing morphine, drugs } \\
\text { containing morphine, drugs } \\
\text { containing diamorphine, } \\
\text { drugs containing cocaine, } \\
\text { cannabis, mixture of cannabis, } \\
\text { cannabis resin, drugs contain- } \\
\text { ing methamphetamine. }\end{array}$ \\
\hline 7. & $\begin{array}{l}\text { Death } \\
\text { Penalty }\end{array}$ & $\begin{array}{l}\text { Imposed upon } 7 \text { narcotics } \\
\text { offences and alternative } \\
\text { with life imprisonment } \\
\text { or imprisonment (further } \\
\text { detail in Table 6) }\end{array}$ & $\begin{array}{l}\text { Imposed upon } 20 \text { offences and } \\
\text { single sentence without any } \\
\text { substitution. }\end{array}$ \\
\hline
\end{tabular}




\begin{tabular}{lll}
\hline $\begin{array}{l}\text { Sanc- } \\
\text { tion for } \\
\text { recidive }\end{array}$ & $\begin{array}{l}\text { Maximum sanction added } \\
\text { with } 1 / 3 .\end{array}$ & Imprisonment and caning. \\
\hline & $\begin{array}{l}\text { There are some offences in } \\
\text { the Narcotics Law Which } \\
\text { are not regulated in the the } \\
\text { Drugs Act. }\end{array}$ & $\begin{array}{l}\text { There are some offences in } \\
\text { the Drugs Act which are not } \\
\text { regulated in the Narcotics } \\
\text { Law. }\end{array}$ \\
\hline
\end{tabular}

Caning sentences in Singapore are based on Criminal Procedure Code on Section 325 to Section 332:

Execution of sentence of caning is forbidden in certain cases

325. - (1) The following persons shall not be punished with caning:

(a) women;

(b) men who are more than 50 years of age at the time of infliction of the caning; and

(c) men sentenced to death whose sentences have not been commuted.

(2) Subject to any other written law, if a person is convicted of one or more offences punishable with caning (referred to in this section as the relevant offences) but the person cannot be caned because subsection (1) (a) or (b) applies, the court may, in addition to any other punishment to which that person has been sentenced, impose a term of imprisonment of not more than 12 months in lieu of the caning which it could, but for this section, have ordered in respect of the relevant offences.

(3) A court may impose a term of imprisonment under subsection (2) notwithstanding that the aggregate of such term and the imprisonment term imposed for any of the relevant offences exceeds the maximum term of imprisonment prescribed for any of those offences.

(4) A Magistrate's Court or District Court may impose a term of imprisonment under subsection (2) notwithstanding that the aggregate sentence of imprisonment (comprising the term of imprisonment imposed under subsection (2) and the combined terms of imprisonment imposed by the court in respect of the relevant offences) exceeds the limits prescribed by section 306 .

(5) The power of a court to impose the additional term of imprisonment under subsection (2) shall not apply in relation to any offence which is committed before the date of commencement of this Division. 


\section{Place for executing sentence of caning}

326. Where a person is sentenced to caning only or where the sentence of caning cannot reasonably be carried out before the release of the person under any sentence of imprisonment, the court must, on the application of the Public Prosecutor, authorise the detention of the person for as long as is reasonably necessary for carrying out the sentence of caning at the place and time that the court directs.

\section{Time of executing sentence of caning}

327.-(1) Where an accused is sentenced to caning in addition to imprisonment, the caning must not be inflicted -

(a) until after the expiration of the time within which notice of appeal may be given under this Code, or any extension of time which may be permitted under this Code; or

(b) if notice is so given, until after the determination of the appeal.

(2) The caning must be inflicted as soon as practicable after the time prescribed in subsection (1) has expired.

\section{Limit on number of strokes}

328. - (1) Notwithstanding any provision of this Code or any other law to the contrary, where an accused is sentenced at the same sitting for 2 or more offences punishable by caning (referred to in this section as the relevant offences), the aggregate sentence of caning imposed by the court in respect of the relevant offences shall not exceed the specified limit.

(2) Subject to any other written law, where an accused would but for subsection (1) have been sentenced to an aggregate sentence of caning which exceeds the specified limit, the court may impose a term of imprisonment of not more than 12 months in lieu of all such strokes which exceed the specified limit.

(3) A court may impose a term of imprisonment under subsection (2) notwithstanding that the aggregate of such term and the imprisonment term imposed for any of the relevant offences exceeds the maximum term of imprisonment prescribed for any of the relevant offences.

(4) A Magistrate's Court or District Court may impose a term of imprisonment under subsection (2) notwithstanding that the aggregate sentence of imprisonment (comprising the term of imprisonment imposed under subsection (2) and the combined terms of imprisonment 
imposed by the court in respect of the relevant offences) exceeds the limits prescribed by section 306 .

(5) The power of a court to impose the additional term of imprisonment under subsection (2) shall not apply in relation to any offence which is committed before the date of commencement of this Division.

(6) In this section, the specified limit is 24 strokes in the case of an adult and 10 strokes in the case of a juvenile.

\section{Models of executing sentence of caning}

329. - (1) The Minister may make rules to prescribe the mode of carrying out the sentence of caning.

(2) Caning shall be inflicted on such part of the person as the Minister from time to time generally directs.

(3) The rattan shall not be more than 1.27 centimetres in diameter.

(4) In the case of a juvenile, caning shall be inflicted with a light rattan.

\section{Caning not to be carried out by instalments}

330.-(1) No sentence of caning shall be executed in instalments.

(2) The maximum number of strokes of the cane that can be inflicted on the offender at any one time is 24 strokes for an adult and 10 strokes in the case of a juvenile.

\section{Medical officer's certificate required}

331. - (1) The punishment of caning may be inflicted only if a medical officer is present and certifies that the offender is in a fit state of health to undergo such punishment.

(2) If, during the execution of a sentence of caning, the medical officer certifies that the offender is not in a fit state of health to undergo the rest of the sentence, the caning must be stopped.

\section{Procedure when punishment cannot be inflicted under section 331}

332.-(1) Where a sentence of caning is wholly or partially prevented from being carried out under section 331, the offender must be kept in 
custody until the court that passed the sentence can revise it.

(2) That court may -

(a) remit the sentence; or

(b) sentence the offender instead of caning, or instead of as much of the sentence of caning as was not carried out, to imprisonment of not more than 12 months, which may be in addition to any other punishment to which he has been sentenced for the offence or offences in respect of which the court has imposed caning (referred to in this section as the relevant offences).

(3) A court may impose a term of imprisonment under subsection (2)(b) notwithstanding that the aggregate of such term and the imprisonment term imposed for any of the relevant offences exceeds the maximum term of imprisonment prescribed for any of those offences.

(4) A Magistrate's Court or District Court may impose a term of imprisonment under subsection (2)(b) notwithstanding that the aggregate sentence of imprisonment (comprising the term of imprisonment imposed under subsection (2)(b) and the combined terms of imprisonment imposed by the court in respect of the relevant offences) exceeds the limits prescribed by section 306 .

(5) The power of a court to impose the additional term of imprisonment under subsection (2)(b) shall not apply in relation to any offence which is committed before the date of commencement of this Division.

Based on Table 5 point 3 , the fine penalty is added with $1 / 3$ to aggravate the sanction in Indonesian Narcotics Law, while in Singapore, imposing death penalty for the offender is given to aggravate the sanction. On the section 33B (1) of the Singapore Drugs Act, the court has discretion to to impose death penalty on specific circumstancess:

33B.-(1) Where a person commits or attempts to commit an offence under section 5 (1) or 7 , being an offence punishable with death under the sixth column of the Second Schedule, and he is convicted thereof, the court:

(a) may, if the person satisfies the requirements of subsection (2), instead of imposing the death penalty, sentence the person to imprisonment for life and, if the person is sentenced to life imprisonment, he shall also be sentenced to caning of not less than 15 strokes; or 
(b) shall, if the person satisfies the requirements of subsection (3), instead of imposing the death penalty, sentence the person to imprisonment for life.

In addition to, if someone is suffering from such abnormality of mind (whether arising from a condition of arrested or retarded development of mind or any inherent causes or induced by disease or injury) as substantially impaired his mental responsibility for his acts and omissions in relation to the offence under section 5 (1) or 7 , judges is better imposing life imprisonment than death penalty. This consideration is not available in Indonesian Narcotics Law.

Recidive in Singapore law is regulated under section:

33A. -

(1) Where a person who has not less than:

(a) 2 previous admissions;

(b) 2 previous convictions for consumption of a specified drug under section 8(b);

(c) 2 previous convictions for an offence of failure to provide a urine specimen under section 31(2);

(d) one previous admission and one previous conviction for consumption of a specified drug under section $8(\mathrm{~b})$;

(e) one previous admission and one previous conviction for an offence of failure to provide a urine specimen under section 31(2); or

(f) one previous conviction for consumption of a specified drug under section 8 (b) and one previous conviction for an offence of failure to provide a urine specimen under section 31(2),

(g) is convicted of an offence under section $8(\mathrm{~b})$ for consumption of a specified drug or an offence of failure to provide a urine specimen under section 31(2), he shall on conviction be punished with:

(i) imprisonment for a term of not less than 5 years and not more than 7 years; and

(ii) not less than 3 strokes and not more than 6 strokes of the cane.

(2) Where a person who has been punished under subsection (1) is again convicted of an offence for consumption of a specified drug under section 8(b) or an offence of failure to provide a urine specimen under section 31(2), he shall on conviction be punished with: 
(a) imprisonment of not less than 7 years and not more than 13 years; and

(b) not less than 6 strokes and not more than 12 strokes of the cane.

In the Article 144 of the Indonesian Narcotics Law, the recidive of minimum 3 years period after the offender released from the prison, the maximum sanction shall be added $1 / 3$. Sentencing based on narcotics quantity in Indonesia is general, based on narcotics Class I, Class II, and Class III. On Singapore, sentencing based on narcotics quantity is specific. The Singapore Drugs Act mentions such narcotics types as opium, opium containing morphine, drugs containing morphine, drugs containing diamorphine, drugs containing cocaine, cannabis, mixture of cannabis, cannabis resin, drugs containing methamphetamine which are classified Class I in Indonesian law.

Narcotics quantity in the Indonesian Narcotics Law is not counted if only it is more than 5 grams of plant. But it is counted based on the plant form which is more than 1 kilograms or 5 trees. Meanwhile in the Singapore Drugs Act, the quantities are are counted as 800 grams, 1200 grams, 20 grams, 30 grams, 10 grams, 15 grams, 330 grams, 500 grams, 660 grams, 1000 grams, 130 grams, 200 grams, 167 grams, and 250 grams.

Death penalty in the Indonesian Narcotics Law is applied only for 7 offences and alternative with imprisonmet. On the other side, in the Singapore Drugs Act, death penalty is applied to 20 offences. The table blow shows the comparison:

Table 6: Offences Threatened by Death Penalty

\begin{tabular}{lll}
\hline \multirow{2}{*}{ No. } & \multicolumn{2}{c}{ Offences Threatened by Death Penalty } \\
\cline { 2 - 2 } & \multicolumn{1}{c}{ The Indonesian Narcotics Law } & \multicolumn{1}{c}{ The Singapore Drugs Act } \\
\hline & $\begin{array}{l}\text { Producing, importing, exporting, } \\
\text { or distributing narcotics Class I, }\end{array}$ & Opium trading with quantity more \\
$\begin{array}{l}\text { Class II or Class III. (Article } 113 \\
\text { poin (2) for narkotics Class I and }\end{array}$ & $\begin{array}{l}\text { more than } 30 \text { grams morphine. } \\
\text { Pasal } 118 \text { ayat (2) untuk narkot- }\end{array}$ & (Section $5(2)(\mathrm{b}))$ \\
ics Class II) & \\
\hline
\end{tabular}


Offer to selling, trading, buying, receiving, to be connector or broker on buying or selling,

2. changing, giving narcotics Class

Narcotics trading (except opium) containing morphine more than 30 grams. (Section 5(3)(b)) 114 poin (2) for narcotics Class I and Article 119 poin (2) for narcotics Class II)

Using narcotics Class I, Class II, or Class III to others or give it to be using by others, and make the Trading narcotics containing

3. user die or get permanent defect. diamorphine more than 30 grams. (Article 116 poin (2) for narkotics (Section 5 (4)(b))

Class I and Article 121 poin (2) for narkotics Class II) Everyone who give order, giving or promising something, giving a chance, recommended, giving Trading narcotics containing co4. easy way, force with threats, caine more than 30 grams. (Section force with violence, cheating, or $5(5)(\mathrm{b}))$ persuade children to do narcotics offences. (Article 133 poin (1))

5. -

Trading marijuana with quantity more than 500 grams (Section 5(6) (b))

Trading mixture of marijuana with 6. - - quantity more than 1000 grams. (Section 5(7)(b))

Trading marijuana resin with quan-

7. tity more than 200 grams.

(Section 5(8)(b))

Trading narcotics containing more

8. than 250 grams methamphetamine. (Section 5(9)(b))

Producing morphine or morphine chrystal, morphine ester or morphine ester chrystal. Producing 9. diamorphine or diamorphine chrystal. Producing cocaine or cocaine chrystal. Producing methamphetamine. (Section 6(2), 6(3), 6(4), 6(5)) 


\begin{tabular}{|c|c|c|}
\hline 10. & - & $\begin{array}{l}\text { Import atau export opium with } \\
\text { quantity more than } 1200 \text { grams and } \\
\text { containing more than } 30 \text { grams of } \\
\text { morphine. (Section } 7(2)(\mathrm{b}) \text { ) }\end{array}$ \\
\hline 11. & - & $\begin{array}{l}\text { Import or export (except opium) } \\
\text { containing morphine more than } 30 \\
\text { grams. (Section } 7(3)(\mathrm{b}))\end{array}$ \\
\hline 12. & - & $\begin{array}{l}\text { Import or export narcotics contain- } \\
\text { ing diamorphine more than } 15 \\
\text { grams. (Section } 7(4)(\mathrm{b}))\end{array}$ \\
\hline 13. & - & $\begin{array}{l}\text { Import atau export narcotics } \\
\text { containing cocaine more than } 30 \\
\text { grams. (Section } 7(5)(\mathrm{b}))\end{array}$ \\
\hline 14. & - & $\begin{array}{l}\text { Import or export marijuana with } \\
\text { quantity more than } 500 \text { grams. } \\
\text { (Section } 7(6)(\mathrm{b}))\end{array}$ \\
\hline 15. & - & $\begin{array}{l}\text { Import or export marijuana mix- } \\
\text { tures with quantity more than } 1000 \\
\text { grams. (Section } 7(7)(\mathrm{b}))\end{array}$ \\
\hline 16. & - & $\begin{array}{l}\text { Import or export marijuana resin } \\
\text { with quantity more than } 200 \text { grams. } \\
\text { (Section } 7(8)(\mathrm{b}))\end{array}$ \\
\hline 17. & - & $\begin{array}{l}\text { Import or export narkotics contain- } \\
\text { ing methamphetamine with quan- } \\
\text { tity more than } 250 \text { grams. (Section } \\
7(9)(\mathrm{b}) \text { ) }\end{array}$ \\
\hline
\end{tabular}

The last analysis is about the disctinction of offences of both laws. Below is the table of narcotics offences and criminal sanction regulation in Indonesia, which is not regulated in Singapore Drugs Act:

Table 7: Indonesian Narcotics Offences

No. Provisions

1. To bring, delivering, loading, or transiting narcotics Class I, Class II, or

1. Class III. (Article 115, article 120, article 125)

Using narcotics towards others or giving narcotics Class I, Class II, or

2. Class III to others for getting used by others. (Article 116, article 121, article 126) 
Sanction for parents or proxy of young person if their parents or proxy

3. do not make a report about children who has been a drug addict (children are persons under 21 years old) (Article 128 poin (1))

4. Corporation who commits narcotics offences. (Article 130)

Everyone who deliberately does not make a report about narcotics

5. offences.

(Article 131)

-A mature drugs addict who deliberately does not make a report.

(Article 134 poin (1))

6. -Family of drugs addict who deliberately does not make a report about that person in their family has been a drug addict. (Article 134 poin (2))

7. Management of pharmacy industry that does not following regulation under Article 45. (Pasal 135)

8. Do money laundering to hide results of narcotics criminal offences (Article 137)

9. Captain or pilot who does not following regulation under Article 27 or Article 28. (Article 139)

- Civil Servant Investigator who does not following regulation under

Article 88 and Article 89. (Article 140 poin (1))

- Police Investigator of Republic Indonesia and National Narcotics

10. Bureau Investigator who does not following regulation under Article 87, Article 89, Article 90, Article 91 poin (2) and poin (3), and poin (4). ((Article 140 poin (2))

11. Chief of Prosecutor who does not following regulation under Article 91 poin (1). (Article 141 poin (1))

Laboratory Officer who forges examination result or with unlawful

12. acr doesn not do obligation to report the examination result to the investigator or prosecutor. (Article 142)

13. Every people who in the term of 3 years commit recidive. (Article 144) The Act is applicable to every people who commit criminal act outside

14. Indonesian territory. (Article 145)

15. The Act is applicable to the foreigners who commit narcotics offences within Indonesian territory. (Article 146)

Criminal sanction if commit narcotics offences for:

a. hospital director, community health centers, medical center, government-owned pharmaceutical preparation storage facilities, and

16. pharmacy.

b. head of the scientific institution.

c. head of the pharmaceutical industry.

d. head of the pharmaceutical wholesaler. (Article147)

17. Fine substitution article. (Article 148)

In the Singapore Drugs Act, offences in the Article 115, 120 and 
125 of the Indonesian Narcotics law are included in trading narcotics offences regulated in the Section 5. Based on Section 2 of the Drugs Act, the meaning of traffics is to to sell, give, administer, transport, send, deliver or distribute; or to offer to help these deed. Meanwhile, in the Indonesian Narcotics Law, this definition are made separated. Selling, receiving, and giving narcotics are regulated in Article 114, Article 119, and Article 124; transporting or sending narcotics are regulated in Article 115, Article 120, and Article 125; distributing narcotics is regulated in Article 113, Article 118, and Article 123, combined with production, export, and import offence. Such for export and import offences in Singapore Law are made separated and listed on Section 7and producting narcotic is regulated under Section 6.

In the Singapore Drugs Act, there is no sanction regulation for sharing narcotics to other or distributing narcotics for public consumtion. Yet there is a regulation for causing or procuring young person or vulnerable person to commit certain offences in Section 12A: "Any person of or above the age of 21 years who causes or procures any young person or vulnerable person to commit any offence under section 5(1) or 7 shall be guilty of an offence." In Section 2, young person means any person who is below 21 years of age. Vulnerable person means any person who suffers from an impairment of, or a disturbance in the functioning of, the mind or brain resulting from any disability or disorder of the mind or brain which impairs the ability to make a proper judgment in relation to the commission of any offence under this Act. Another provisions in the Section 5(1) is regulating the narcotics trafficking, and Section 7 is regulating import and export of narcotics. There are many offences on the Singapore Drugs Act which are not regulated in the Indonesian Narcotics Law:

Table 8: Singapore Narcotics Offences

\begin{tabular}{ll}
\hline No. & Provisions \\
\hline 1. & $\begin{array}{l}\text { Person who have in his possession any pipe, syringe, utensil, apparatus } \\
\text { or other article intended for the smoking, administration or consump- } \\
\text { tion of a controlled drug. (Section 9) }\end{array}$ \\
\hline
\end{tabular}


Being the owner, tenant, occupier or person in charge of any place or premises, to permit or suffer such place or premises or any part thereof

2. to be opened, kept or used for the purpose of smoking, administration or consumption of

any controlled drug; or the unlawful trafficking in or the unlawful manufacturing of any controlled drug. (Section 11)

3. Arranging or planning gatherings where controlled drugs are to be consumed or trafficked. (Section 11A)

Fail to comply with any lawful requirement of any officer of the

4. Bureau, police officer, officer of customs or other public officer in the execution of his duty under this Act. (Section 30(1)(b))

Fail, without reasonable excuse, to furnish such information in his pos-

5. session as may be required by any officer of the Bureau, police officer, officer of customs or other public officer. (Section 30(1)(c))

A person who fails, without reasonable excuse, to provide a specimen

6. of his urine within such time as may be required by any of the officers referred to in subsection (1) shall be guilty of an offence. (Section $31(2))$

A person who fails, without reasonable excuse, to provide specimens of his hair of such type and quantity as may be required by any of the

7. officers referred to in subsection (1) shall be guilty of an offence. (Section $31 \mathrm{~A}(2))$

Section $11 \mathrm{~A}(1)$ stated that:

Where there is a gathering of 2 or more persons in any place, any person who arranges or plans the gathering with the knowledge that any controlled drug is, or is to be, consumed or trafficked at that gathering shall be guilty of an offence and shall on conviction:

(a) be punished with imprisonment for a term of not less than 3 years and not more than 20 years; and

(b) be liable to caning of not more than 10 strokes.

Section $11 \mathrm{~A}(2)$ explains that a person may be guilty of an offence under subsection (1) notwithstanding that he does not supply any controlled drug to be consumed or trafficked at that gathering.

Failure to comply with any lawful requirement in the Section 30(1)(b) means failure to fulfill or failure to obey the law requirement from bureau officer, police, or public officer to implement any obligation under this Act. Failure to give information on the Section 30(1) (c) means fail without reasonable excuse, to provide any information which is needed by bureau officer, police officer, or public officer. 
Failure to provide urine specimen on the Section 31(2) can be punished as based on the provision under Section 31(1) every bureau, immigration or police officer not below the rank of sergeant may, if the offender reasonably suspects any person to have committed an offence under section 8 (b), require that person to provide a specimen of his urine for urine tests to be conducted under this section. Section 8 (b) is regulating about narcotics possession and consumption.

Failure to provide hair speciments for hair test under Section $31 \mathrm{~A}(2)$ still relate with offences under Section $8(\mathrm{~b})$. If the offender is suspected by the officer then the offender should give his/her hair sample for inspection.

Although Indonesia and Singapore have different sanction regulation, each of narcotics law has its own strategic way to prefent narcotics offence in the country. Below are the pros and cons of narcotics criminal sanction in Indonesia and Singapore:

Table 9: Pros of Criminal Sanction in Indonesia and Singapore

\begin{tabular}{|c|c|c|}
\hline No. & Indonesia & Singapore \\
\hline 1. & $\begin{array}{l}\text { Humanity of narcotics offenders } \\
\text { is still considered, as Indonesia } \\
\text { does not give death sentences as } \\
\text { single sentences. }\end{array}$ & $\begin{array}{l}\text { High minimum and maximum lim- } \\
\text { its of the sanctions bring deterrent } \\
\text { effect for the offenders. }\end{array}$ \\
\hline 2. & $\begin{array}{l}\text { Criminal offense formulation is } \\
\text { wide and exhaustive, encompass } \\
\text { a lot of aspects. }\end{array}$ & $\begin{array}{l}\text { Some section which impose death } \\
\text { sentence as single punishment } \\
\text { for some kind of narcotics is very } \\
\text { effective to press down narcotics } \\
\text { offences rate in Singapore. }\end{array}$ \\
\hline 3. & $\begin{array}{l}\text { Criminal sanction formulation } \\
\text { for corporation is heavier. }\end{array}$ & $\begin{array}{l}\text { Criminal sanction formulation } \\
\text { and regulation is clear, exhaustive, } \\
\text { simple, easy to understand and ef- } \\
\text { fective. }\end{array}$ \\
\hline 4. & $\begin{array}{l}\text { There is aggravation } 1 / 3 \text { of sanc- } \\
\text { tion. }\end{array}$ & $\begin{array}{l}\text { Fine penalty is rational and can be } \\
\text { implemented as well. }\end{array}$ \\
\hline 5. & $\begin{array}{l}\text { There are sanctions for public in- } \\
\text { vestigator and police investigator } \\
\text { or narcotics bureau investigator. }\end{array}$ & $\begin{array}{l}\text { There is caning penalty that give } \\
\text { direct physics illness as cumulative } \\
\text { sentences. }\end{array}$ \\
\hline 6. & Heavier sanction for recidive. & - \\
\hline 7. & $\begin{array}{l}\text { Regulation on rehabilitation is } \\
\text { more exhaustive and easy to get } \\
\text { rehabilitation. }\end{array}$ & - \\
\hline
\end{tabular}


Table 10: Cons of Narcotic Criminal Sanction in Indonesia and Singapore

\begin{tabular}{|c|c|c|}
\hline No. & Indonesia & Singapore \\
\hline 1. & $\begin{array}{l}\text { The term of imprisonment as sub- } \\
\text { titution for fine is too short. (Article } \\
148 \text { Law Number } 35 \text { Year 2009) This } \\
\text { give an easier way for offender not } \\
\text { to pay the fine and prefer imprison- } \\
\text { ment. }\end{array}$ & $\begin{array}{l}\text { The high minimum limit of sen- } \\
\text { tencing decrease the state budget } \\
\text { to fund the prisoners during the } \\
\text { period of imprisonment. }\end{array}$ \\
\hline 2. & $\begin{array}{l}\text { Suggestion for the judge to give } \\
\text { rehabilitation for narcotics offender } \\
\text { does not bring deterrence effect. }\end{array}$ & Rehabilitation is rarely given. \\
\hline 3. & $\begin{array}{l}\text { Narcotics offender would not pay } \\
\text { the fine because the its high amount } \\
\text { of price. They could not afford it. }\end{array}$ & $\begin{array}{l}\text { Death penalty as single sanction } \\
\text { and canning are violations to } \\
\text { human rights. }\end{array}$ \\
\hline 4. & $\begin{array}{l}\text { As Indonesia adopt the mixed } \\
\text { theory between absolute and rela- } \\
\text { tives theories, the criminal sanctions } \\
\text { give less effect towards offender. }\end{array}$ & $\begin{array}{l}\text { Alternative criminal stelsel of } \\
\text { imprisonmentor fine in some } \\
\text { criminal sanction potentially } \\
\text { could give a chance for the } \\
\text { offender to be released if it is set- } \\
\text { enced that he/she shall pay fine }\end{array}$ \\
\hline 5. & $\begin{array}{l}\text { Offense arrangement in every } \\
\text { article is less practical as many same } \\
\text { offense which rule the same thing } \\
\text { is placed in different article. It will } \\
\text { be more effective to place same of- } \\
\text { fenses in one article. }\end{array}$ & $\begin{array}{l}\text { The regulation of canning is } \\
\text { gender biased as women are not } \\
\text { excluded from canning. }\end{array}$ \\
\hline
\end{tabular}

\section{Conclusion}

Both Indonesia and Singapore Laws have their own advantages and disadvantages, pros and cons in their formulating narcotics sanction. The purpose of Narcotics Law through its sanction is to press down the rate of narcotics offences in the country and protect its generations from narcotics abuse. So, the decrease of offences rate would mean the effectiveness of criminal sanction. The criminal sanction for narcotics offence in Indonesia and Singapore is deeply affected by its system and philosophy of law. Despite their intention to eradicate narcotics abuse radically, both countries have implemented different ways to their sanction. In this matter, Singapore looks more severe in its implementation of the sanction against drugs offender 
than that of in Indonesia and have advantege to reduce into miminum level of effence. However, Singapore is challenged as long as the human rights implementation is concerned. Towards this part, Indonesia looks more humanized, yet it has to face more problems from such offence. Since Indonesia also consider religious and adat laws, it is suggested that both instruments of law are adopted to Indonesian Narcotics Law, such as the application of caning, isolation, and other adat or religious, instead of Singapore's, sanction against drugs abuse. This would made Indonesian Narcotics Law not only humanized, but would also be taken into account by any element of the country so that the mission to eradicate drugs or narcotics offence would be achieved.

\section{Bibliography}

\section{Legal Documents}

Indonesia, Undang-Undang Nomor 35 Tahun 2009 tentang Narkotika (Law Number 35 / 2009 regarding Narcotics)

Singapore, Misuse of Drugs Act.

The UN Convention against the Illicit Traffic in Narcotic Drugs and Psychotropic Substances of 1988

The UN Convention on Psychotropic Substances of 1971

\section{Books and Journals}

Ahmad, Beni Saebani, Syahrul Anwar, dan Ai Wati, 2016, Perbandingan Sistem Hukum Pidana, Bandung, Pustaka Setia.

Andrisman, Tri, 2009, Asas-Asas Dan Dasar Aturan Hukum Pidana Indonesia (Principals and Ground Regulation of Criminal Law), Bandar Lampung, Ula.

Heryansyah, Despan \& Muhammad Hidayatullah, 2018, "Problems of Law Enforcement and Ideas of Paradigm Prophetic in Indonesia," Jambe Law Journal, Vol. 1 No. 1

Hikmawati, Puteri, 2011, "Analisis Terhadap Sanksi Pidana Bagi Pengguna Narkotika” (Analysis Towards Criminal Sanction For Drugs Addict)," Jurnal Negara Hukum, Vol. 2, No. 2, November. 
Hor, Michael, 2004, "The Death Penalty in Singapore and International Law", Singapore Year Book of International Law, Issue 8, Singapore: National University of Singapore.

Lynch, Colman, "Indonesia’s Use of Capital Punishment For DrugTrafficking Crimes: Legal Obligations, Extralegal Factors, and The Bali Nine Case", COLUMBIA HUMAN RIGHTS LAW REVIEW, vol. 40 .

Cheah, Wui Ling, 2018, "Developing a People-Centered Justice in Singapore: In Support of Pro Bono and Innocence Work", Cincinnati Law Review, Volume 80, Issue 4, Ohio: University of Cincinnati.

Marlina, 2011, Hukum Panitensier (Penology), Bandung, PT. Refika Aditama.

Nawawi, Barda Arief, 2011, Perbandingan Hukum Pidana (Criminal Comparative Law), Edisi ke Sembilan (Ninth Edition), Jakarta, Rajawali.

Prakoso, Djoko and Agus Imunarso, 1987, Hak Asasi Tersangka dan Peranan Psikologi dalam Konteks KUHAP (Human Rights and Psychology Role in Criminal Procedure Code Context), Jakarta, Bina Aksara.

Ramli, Samsul and Fahrurrazi, 2014, Bacaan Wajib Swakelola Pengadaan Barang/Jasa, Jakarta, Visimedia Pustaka.

Susila, Muh Endriyo, 2014, The Criminal Law of Indonesia, Yogyakarta, Pensil Komunika.

Syamsuddin, Aziz, 2016, Tindak Pidana Khusus (Special Crime), Fifth Edition, Jakarta, Sinar Grafika.

Radics, George Baylon, 2014, “Singapore:A ‘Fine’ City: British Colonial Sentencing Policies and its Lasting Effects on the Singaporean Corporal State", Santa Clara Journal of International Law, California, United States, Vol. 12, No. 57, 27 Mei.

\section{Website}

Ashok Kumar Mirpuri, "Singapore is Winning the War on Drugs. Here'sHow", https: / www.washingtonpost.com/opinions / singapore-is-winning-the-war-ondrugs-heres-how/2018/03/11/ 
Monalisa, Sri Rahayu, \& Dheny Wahyudhi

b8c25278-22e9-11e8-946c-9420060cb7bd_story.html. Accessed on 30 December 2019. 